\title{
Gravity Anomaly in Kelud, Kasinan-Songgoriti, and Arjuno-Welirang Volcano Hosted Geothermal Area, East Java, Indonesia
}

\author{
Novita Wahyuningsih, Sukir Maryanto, Wiyono
}

\begin{abstract}
This study aims to determine the relationship of heat reservoirs in the Kelud, Kasinan-Songgoriti, and Arjuno-Welirang geothermal systems based on gravity data analysis. Gravity data are obtained from Geodetic Satellite (GEOSAT) and European Remote Sensing-1 (ERS-1) Satellite which have been corrected to free air correction. The result of gravity data analysis is in the form of a complete Bouguer anomaly which represents the gravity anomaly below the surface. The results of the complete Bouguer anomaly value obtained were $-15,238 \mathrm{mGal}$ to $86,087 \mathrm{mGal}$. Based on these results, regional anomalies and residual anomalies will be separated to determine the depth of the two anomalies. $3 D$ modeling was carried out based on the complete Bouguer anomaly data to determine the reservoir relationships in the Kelud, Kasinan-Songgoriti, and Arjuno-Welirang geothermal systems.
\end{abstract}

Keywords : gravity data, complete Bouguer anomaly, reservoir, geothermal, GEOSAT and ERS-1 Satellite.

\section{INTRODUCTION}

Indonesia is located in the Pacific Ring of Fire region, where there is an active plate meeting. The resulting effect is the emergence of volcanic activity along the path through the ring of fire. The magnitude of volcanic activity gives rise to considerable geothermal potential [1]. Geothermal is one of the environmentally alternative energy sources in the form of thermal energy stored in subsurface rocks [2]. Geothermal potential in Indonesia is one of the largest in the world, with a potential of 11,073 MW and reserves of 17,506 MW [3]. Geothermal potential in Indonesia is mostly located in the Java and Sumatra Island regions, one of which is in East Java, those are Kelud, Kasinan-Songgoriti, and Arjuno-Welirang regions.

Manifestations in Kelud, Kasinan-Songgoriti, and Arjuno-Welirang areas are forming of fumaroles, solfatara, and hot springs. In Kelud crater, there is manifestation that form of fumarole. Meanwhile, around the summit of Mount Welirang there are manifestations in the form of fumarole and solfatara [3]. In the Kasinan-Songgoriti areas there are

Revised Manuscript Received on January 10, 2020.

* Correspondence Author

Novita Wahyuningsih, Magister Program, Department of Physics, Universitas Brawijaya, Malang 65415, East Java, Indonesia. (Email: novitawahyuningsih12@gmail.com).

Sukir Maryanto*, Department of Physics, Brawijaya Volcanology and Geothermal Research, Universitas Brawijaya, Malang 65415, Indonesia. (Email: sukir@ub.ac.id).

Wiyono, Department of Physics, Universitas Brawijaya, Malang 65415, Indonesia. (Email: wiyonogeofis@ub.ac.id). manifestations of hot springs [4]. There are also manifestations of hot springs in the Cangar area in Batu City, and Padusan in the Mojokerto Regency [5].

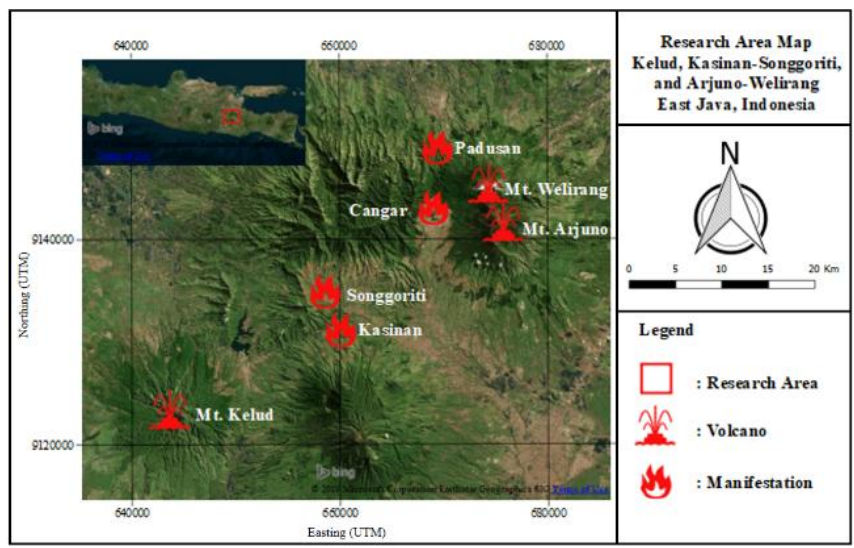

Fig. 1. Research area map

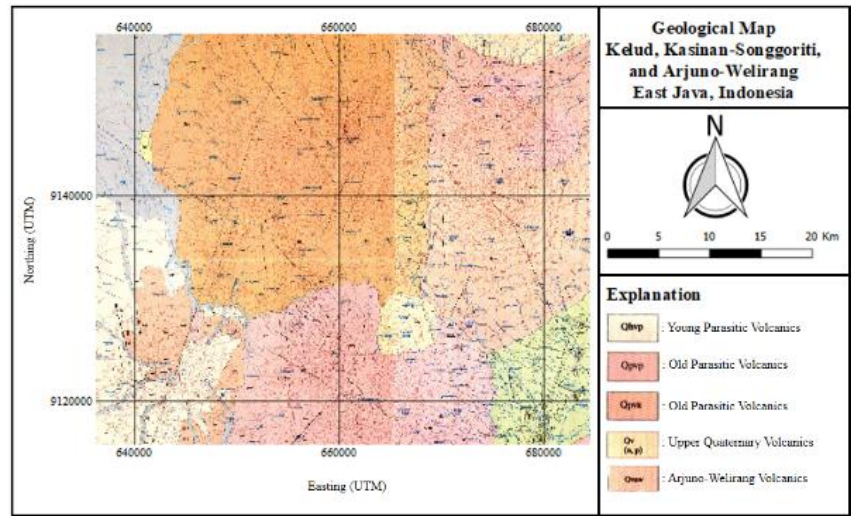

Fig. 2. Geological map of research area

Mount Kelud located in the region of Kediri Regency, East Java, is one of the active volcanoes on the island of Java. There are several rock formations in the Kelud, which are dominated by igneous andesite, basalt, volcanic sand and lava [2]. Morphology of Mount Kelud is irregular in shape, causing of the explosive eruption of Mount Kelud which was followed by the process of lava dome formation [6].

Kasinan-Songgoriti areas belong to Batu City region, which is surrounded by ancient volcanoes, that are Mount Panderman, Mount Kawi, and Mount Butak [7]. Geological formation in Kasinan-Songgoriti regions is Upper Quaternary Volcanics formation, which consist of volcanic breccias, lava, tuff, tuff breccias, agglomerates, and lava.

Arjuno-Welirang, located 
in East Java, is the Quaternary age. Geothermal systems in Arjuno-Welirang have steep terrain and are associated with volcanic systems [8].

The existence of heat source in Arjuno-Welirang comes from magmatic sources [9]. Geothermal manifestations that appear in Arjuno-Welirang, formed of fumaroles and solfatara that emerge from the crater of Mount Welirang, as well as manifestations of hot springs that appear in Cangar and Padusan which are under the Mount Arjuno-Welirang.

The morphology of Kelud volcano was steep, irregular sharp, and there was a lake crater. Type of Kelud volcano is stratovolcano that has heat eruption cloud deposits, and consists of pyroclastic rocks and andesitic lava [13]. Kasinan-Songgoriti-Cangar hot springs areas are associated with Arjuno-Welirang complex, Mount Kawi complex, and Kelud volcano [11].

Arjuno-Welirang complex is a quaternary active volcano which belongs to Arjuno-Welirang volcano complex. Arjuno-Welirang volcano complex is a volcano hosted geothermal system that associated with volcanic system and has steep terrain [8]. Manifestations of Cangar and Padusan hot springs are located under of Mount Arjuno-Welirang, where Cangar fault is the main controlling factor of Cangar hot springs, and Padusan fault is the main controller of Padusan hot springs in Mojokerto [5]. The geological structures in Arjuno-Welirang complex are based on the fault formed. The Cangar fault, the Pucung fault, and the Claket fault, where these faults are possible to control the appearance of Cangar hot spring. The Padusan fault, the Kemiri fault, and the Bakal fault, where these faults are possible to control the appearance of Padusan hot spring [8]. The geological structure of Kelud, Kasinan-Songgoriti, and Arjuno-Welirang is associated with volcanic activity that surrounded the research area [12].

\section{METHOD}

The gravity method is one of the subsurface exploration methods. Gravity measurements are carried out by measuring the gravitational field at a measuring point in an area. The gravity method works with the working principle of comparing the mass density of an object below the surface to the mass density in the environment around the observation point. The basic principle of the gravitational method is Newton's Law of Gravity which explains the force acting between two points of mass, which is formulated as in

$$
\boldsymbol{F}=G \frac{m_{1} m_{2}}{r^{2}} \hat{\boldsymbol{r}}
$$

Where:

$\boldsymbol{F}:$ the force acting between two masses $m_{1}$ and $m_{2}$.

$\widehat{\boldsymbol{r}}$ : directional vector from $m_{2}$ to $m_{l}$.

$G$ : the gravitational constant, in SI is $6.672 \times 10^{-11} \mathrm{Nm}^{2} / \mathrm{kg}^{2}$.

This research are located at coordinate positions 7०38'31.29" - 7०58'15.40" S and $112^{\circ} 15 ' 51.36^{\prime \prime}$ $112^{\circ} 37^{\prime} 44.63^{\prime \prime} \mathrm{E}$, which cover the geothermal manifestation areas of Kelud, Kasinan-Songgoriti and Arjuno-Welirang , East Java. The purpose of this study is to identify the relation of heat reservoir from the three geothermal manifestations of the study area. The gravity data used in this study is satellite gravity data obtained from the Geodetic Satellite (GEOSAT) and European Remote Sensing-1 (ERS-1) Satellite pages with the website address http://topex.ucsd.edu/cgi-bin/get_data .cgi [10].

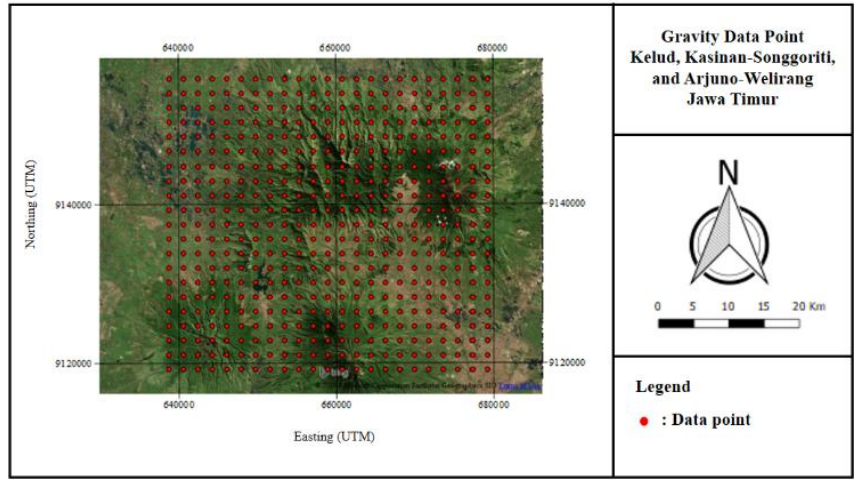

Fig. 3. The gravity data point of research area

\section{RESULTS AND DISCUSSION}

\section{A. Complete Bouguer Anomaly}

The results obtained from processing gravity data in the form of a complete Bouguer anomaly. Complete Bouguer anomaly describes the total subsurface anomaly of the study area, which consists of regional anomaly and residual anomaly.

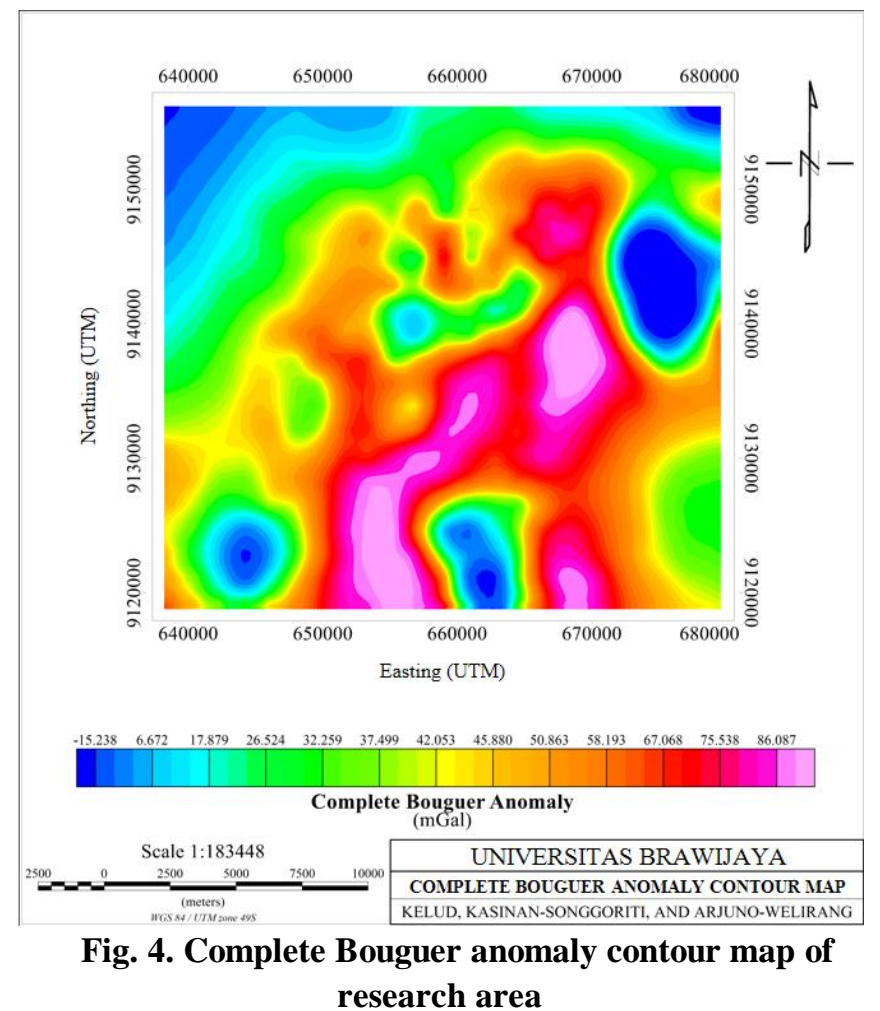

Figure 4 shows the complete Bouguer anomaly contour map of the study area.

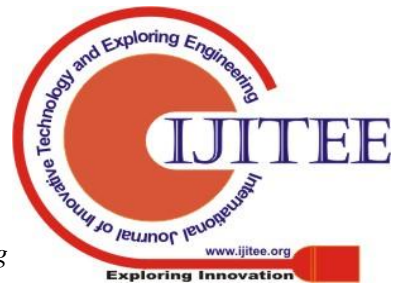


The range of complete Bouguer anomaly values are $-15,238$ $\mathrm{mGal}$ to $86,087 \mathrm{mGal}$, In this study, the complete Bouguer anomaly was used as basic for the gravity data inversion modeling.

\section{B. Separation of Regional and Residual Anomalies}

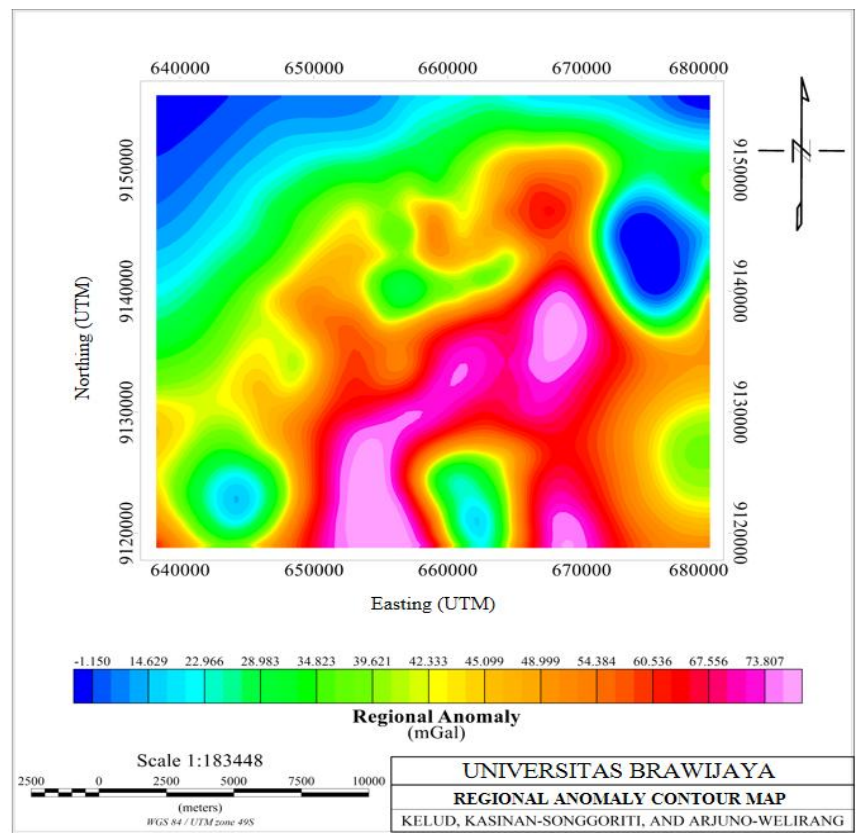

Fig. 5. Regional anomaly contour map of research area

Figure 5 shows the regional anomaly contour map of the study area. Regional anomalies describe subsurface anomalies that are deep. The range of regional anomaly values is $-1,150 \mathrm{mGal}$ to $73,807 \mathrm{mGal}$.

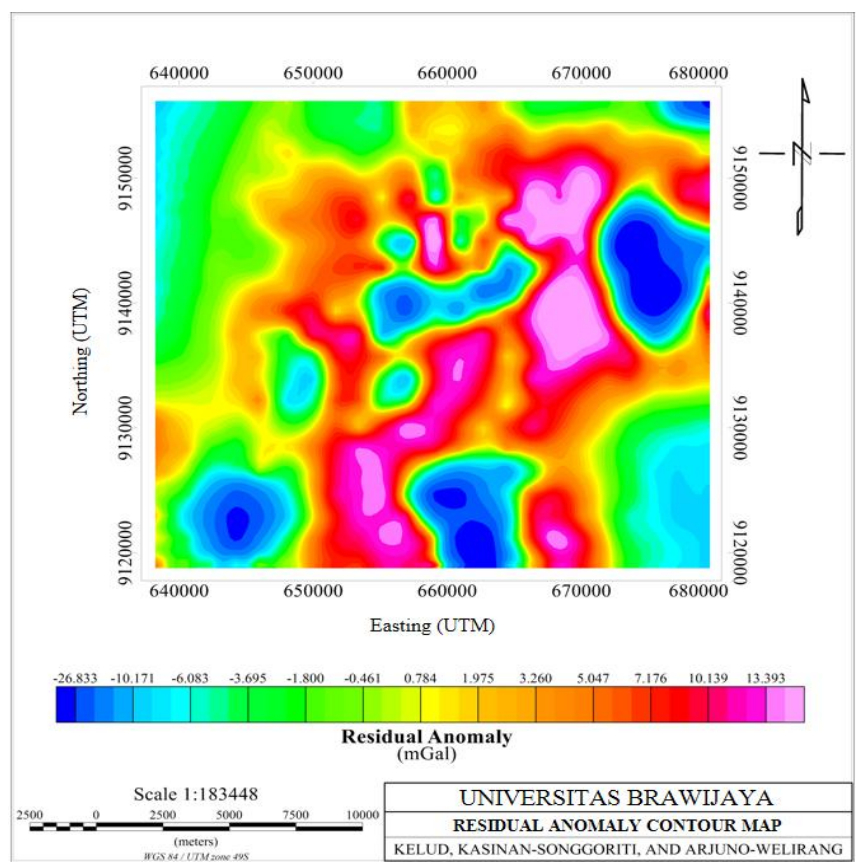

Fig. 6. Residual anomaly contour map of research area

Figure 6 shows anomaly residual contour map of the study area. Residual anomaly describes shallow subsurface anomalies. Residual anomaly value is ranging from $-26,833$ mGal to $13,393 \mathrm{mGal}$.

\section{Interpretation of Gravity Data}

In this research, the inversion modelling based on complete Bouguer anomaly was consists of two cross sections. A- $\mathrm{A}^{\prime}$ is the cross section that oriented from the manifestation of Kelud to the manifestation of Kasinan-Songgoriti, with contrast density value ranging from $-0,581 \mathrm{~g} / \mathrm{cm}^{3}$ to $0,318 \mathrm{~g} / \mathrm{cm}^{3}$.
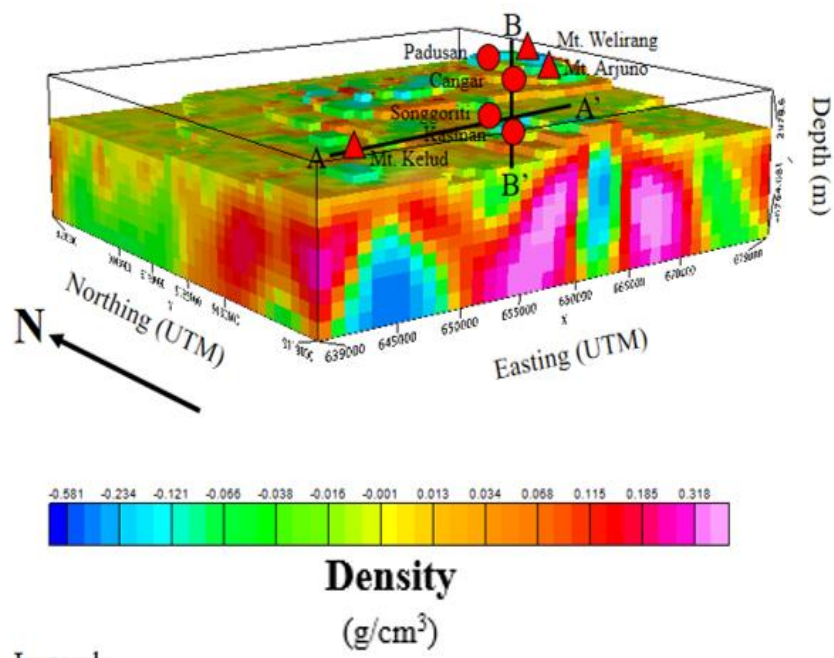

Legend:
$\Delta$ : Volcano
: Hot spring
: Slice

Fig. 7. Inversion data model of research area

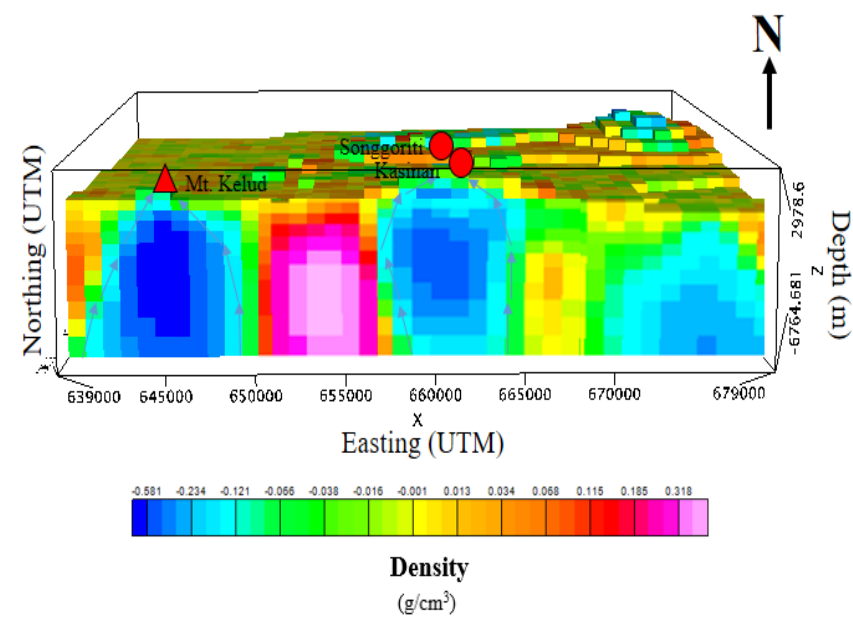

Legend:

\section{$\Delta$ : Volcano \\ : Hot spring}

Fig. 8. A-A' cross section of research area

A-A' cross section with a range of low contrast density values of $-0,581 \mathrm{~g} / \mathrm{cm}^{3}$ to $-0,121 \mathrm{~g} / \mathrm{cm}^{3}$, the reservoir is suspected to be found at a depth of approximately 50-100 meters from the surface, with a thickness of about 3500 4500 meters.

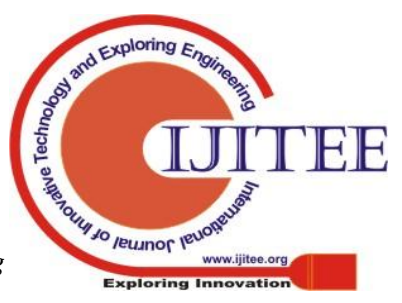


B-B' is the cross section that oriented from the manifestation of Kasinan-Songgoriti to the manifestation of Arjuno-Welirang, with contrast density value ranging from $-0,581 \mathrm{~g} / \mathrm{cm}^{3}$ to $0,318 \mathrm{~g} / \mathrm{cm}^{3}$.

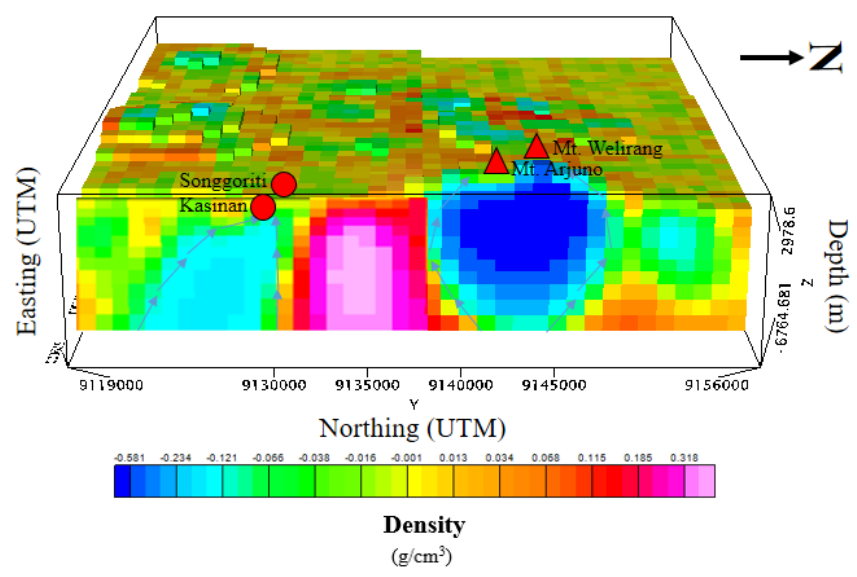

Legend:

$\Delta \quad$ : Volcano

: Hot spring

Fig. 9. B-B' cross section of research area

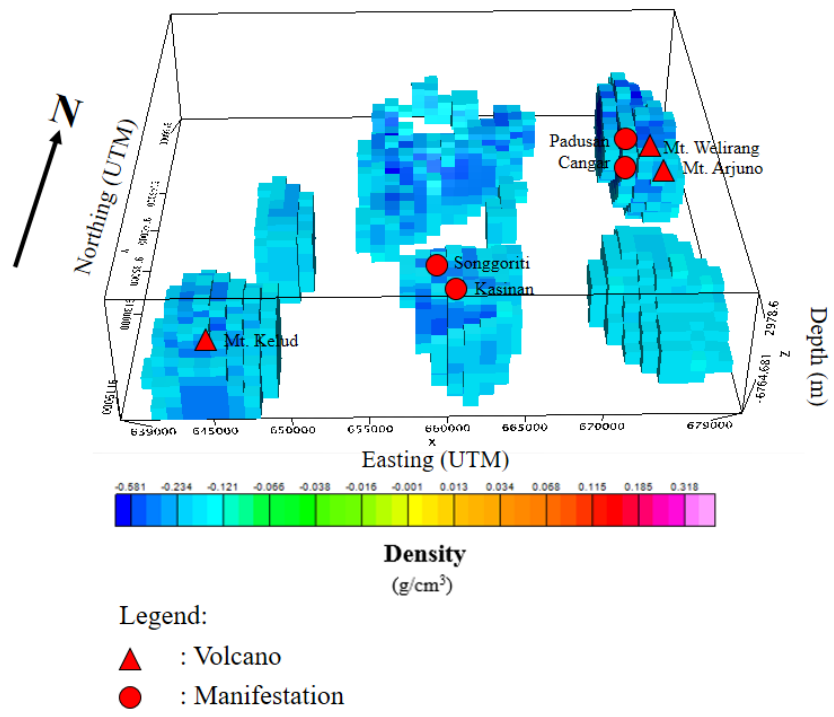

Fig. 10. Clipping data of research area

B-B' cross section with a range of low contrast density values of $-0,581 \mathrm{~g} / \mathrm{cm}^{3}$ to $-0,121 \mathrm{~g} / \mathrm{cm}^{3}$, the reservoir is suspected to be found at a depth of approximately 20-50 meters from the surface, with a thickness of about 4000-5000 meters. Heat reservoirs are indicated by rock bodies that are dark blue to light blue which have a relatively low contrast density value that is possible as volcanic breccia rocks. In a geothermal system, there is a type of cap rock. When reviewed based on information contained in the regional geological map of the study area, in Kelud, Kasinan-Songgoriti, and Arjuno-Welirang areas there is a type of rock that has the characteristics and types of distribution that are very potential as a layer of cap rock, that is tuff. Tuff is a type of rock that has high permeability, that means if its presence is founded in the geothermal area, it can be estimated that there is a structure which is a pathway for the movement of thermal fluid to the surface.
The continuity of Kelud, Kasinan-Songgoriti, and Arjuno-Welirang geothermal systems can be done by making clipping data on the inversion modeling results. Clipping data is done by selecting a low contrast density value which is interpreted as a heat source and as a reservoir rock. The heat source is represented in dark blue, while reservoir rocks are represented in light blue. The results of clipping data modeling are based on the range of reservoir rock density values in the Kelud, Kasinan-Songgoriti, and Arjuno-Welirang geothermal systems.

\section{CONCLUSION}

Based on the interpretation and analysis of gravity data, it can be seen that Kelud, Kasinan-Songgoriti and Arjuno-Welirang geothermal systems are not from one reservoir rock. The three manifestations of geothermal systems have different reservoir rocks. Where the source of manifestation in Kelud comes from rocks under the surface of Mount Kelud that come out through the Kelud crater. The reservoir rocks of Kasinan-Songgoriti geothermal manifestation areas come from Mount Kawi-Butak-Panderman. Arjuno-Welirang geothermal manifestation comes from the active volcanism of Mount Arjuno-Welirang.

\section{ACKNOWLEDGMENT}

The authors deliver their gratitude to Brawijaya Volcano and Geothermal Research Center (BRAVO GRC) of Universitas Brawijaya, Malang, East Java and to Hibah Penelitian Unggulan Tahun Anggaran 2019, Nomor: 697.20/UN 10.C10/PN/2019 for the fund, support, and valuable thoughts as well as the Geodetic Satellite (GEOSAT) and European Remote Sensing-1 (ERS-1) Satellite that has provided the gravity data for the present research.

\section{REFERENCES}

1. Prayogo, A., Determination of Heat Reservoar Distribution in Potential Geothermal Area Tiris-Lamongan, Probolinggo, East Java Based on Remote Sensing and Magnetic Data, Malang: Physics Department, Faculty of Mathematics and Sciences, Universitas Brawijaya, 2019. (in Indonesian)

2. Rifaldi, R., Kristanto, A., Ristanti, N. A., Yuliandari, I., Koswara, I., Perwita, C. A., Estimation of Hydrothermal Flow Direction with Gravity Method Using Satellite Imagery Data in the Kelud Mountain Area of Kediri Regency, Proceeding on the $10^{\text {th }}$ National Earth Science Seminar. The Role of Earth Sciences Research in Infrastructure Development in Indonesia. September 13 - 14, 2017, Grha Sabha Pramana, Yogyakarta. (in Indonesian).

3. Ministry of Energy and Mineral Resources, Directorate of Geothermal, Geothermal Potential in Indonesia, 1st ed.; Geothermal Directorate, Ministry of Energy and Mineral Resources: Jakarta, Indonesia, 2017. (in Indonesian)

4. Mawarni, L. W., Identification of the Geothermal Reservoir Based on the Magnetic and Remote Sensing Methods in Kasinan-Songgoriti, Batu Region, East Java. Malang: Physics Department, Faculty of Mathematics and Sciences, Universitas Brawijaya, 2019. (in Indonesian)

5. Maryanto, S., (2017). Geo Techno Park Potential at Arjuno-Welirang Volcano Hosted Geothermal Area, Batu, East Java, Indonesia (Multi Geophysical Approach). Conference Paper in AIP Conference Proceedings November 2017. 8th International Conference on Global Resource

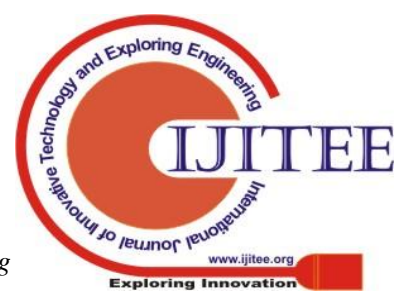


Conservation (ICGRC 2017) AIP Conf. Proc. 1908, 030012-1-030012-12. DOI: https://doi.org/10.1063/1.5012712.

6. Santosa, B. Jaya, Mashuri, Sutrisno, W.T., Interpretation of Magnetic Methods for Determination of Subsurface Structures Around Kelud Mountain, Kediri Regency. Journal of Physics Research and Its Applications (JPFA) Vol. 2 No. 1, Juni 2012. ISSN: 2087-9946. (in Indonesian)

7. Mawarni, Laily W., Maryanto, S., Nadhir, A., Magnetic Method Used in Geothermal Reservoirs Identification in Kasinan-Songgoriti, East Java, Indonesia. Environmental and Earth Sciences Research Journal Vol. 5, No. 4, December, 2018, pp. 87-93. DOI: https://doi.org/10.18280/eesri.050402.

8. Utama, Harijoko, \& Husein, Volcanism and Geological Structure Study for Early Geothermal Exploration in the Arjuno Welirang Volcano Complex. Proceeding, National Earth Seminar 9th, October 6 - 7, 2016 Grha Sabha Pramana, Yogyakarta. (in Indonesian)

9. Sumotarto, U., Geothermal Energy Potential of Arjuno and Welirang Volcanoes Area, East Java, Indonesia. International Journal of Renewable Energy Research. Vol.8, No.1, March, 2018.

10. Marthen, Yoel, Identification of Geological Structure and Geothermal System of Ijen Caldera Complex Based on Gravity and Satellite Imagery. Malang: Physics Department, Faculty of Mathematics and Sciences, Universitas Brawijaya, 2016. (in Indonesian)

11. Maryanto, S., Preliminary Investigation of Volcano Hosted Geothermal Area at Kasinan-Songgoriti-Cangar, Batu City, Based on Gravity-Seismic Methods, The $8^{\text {th }}$ Annual Basic Science International Conference. AIP Conference Proceedings 2021, 050010 (2018), DOI: https://doi.org/10.1063/1.5062760.

12. Wahyuningsih, N., Maryanto, S., Wiyono., Preliminary Study of SRTM DEM Data in Kelud, Kasinan-Songgoriti, and Arjuno-Welirang, East Java, Indonesia. IOSR Journal of Applied Geology and Geophysics (IOSR-JAGG), e-ISSN: 2321-0990, p-ISSN: 2321-0982. Volume 7, Issue 5 Ser II (Sep.- Oct. 2019), PP 01-08. DOI: 10.9790/0990-0705020108.

13. Maryanto, S., Nadhir, A., Santoso, D.R., "Implementation of Town Watching and Development of Observatory for Community Education in Volcano Hazard Mitigation (Study Case at Kelud and Arjuno-Welirang Volcanoes, East Java, Indonesia), Conference Paper, June 2018, DOI https://doi.org/10.1145/3233347.3233349.

14. Widyaminudiin, M., "Secondary Structure Identification Using Derivative Analysis of Gravity Anomaly on Hydrothermal System Case Study Cangar East Java Geothermal Area". Malang: Physics Department, Faculty of Mathematics and Sciences, Universitas Brawijaya, 2017. (in Indonesian)

\section{AUTHORS PROFILE}

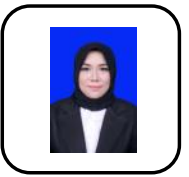

Novita Wahyuningsih, She is currently a postgraduate student at Universitas Brawijaya. She majored in physical sciences with an interest in geophysics. She is a member of the Brawijaya Volcano and Geothermal Research Center, Universitas Brawijaya.

Sukir Maryanto, $\mathrm{He}$ is a Professor at Universitas Brawijaya. He currently works at Physics Department, Universitas Brawijaya. He is the Principal Investigator of the Brawijaya Volcano and Geothermal Research Center. He has completed his Ph.D. from Koyoto University in 2007. He has published more than 50 international journals relating to the volcano and geothermal systems.

Wiyono, He is a lecturer in Physics Department, Faculty of Mathematics and Sciences, Universitas Brawijaya. He has completed Doctor title from Universitas Brawijaya. 